\title{
Exploring the Impact of Innovation between Japanese KIBS and Clients
}

\author{
${ }^{a}$ CAO Yong, ${ }^{a}$ LI Yang, ${ }^{b}$ NAGAHIRA Akio \\ ${ }^{a}$ School of Management, Huazhong University of Science and Technology, Wuhan 430074, P.R China \\ ${ }^{b}$ Graduate School of Engineering, Tohoku University, Sendai City, Miyagi 980-8579, Japan
}

\begin{abstract}
The purpose of this paper is to propose an analytical framework to explain why knowledge intensive business services (KIBS) have become an important strategy for many firms. It will especially examine why the relationships between KIBS and clients are different by analyzing the impact of KIBS for different types of innovation and different divisions, and also what and how the service delivery method contributes to each type of innovation for Japanese manufacturing corporations (JMCs). The results show that firstly, KIBS provide professional knowledge to accelerate the different innovation of their clients; secondly, KIBS contribute more to the radical innovation of a client than incremental innovation; and the thirdly, face-to-face delivery is the most efficient method of service from KIBS to the JMCs.
\end{abstract}

Index Terms: KIBS; JMCs; Innovation; Impact; Client-side

(C) 2012 Published by MECS Publisher. Selection and/or peer review under responsibility of the International Conference on E-Business System and Education Technology

\section{Introduction}

Recently KIBS have become increasingly more important, particularly in developed countries where there is a shift from an industrial economy to a knowledge-based economy. Because of the importance of knowledge intensive departments such as R\&D, sales, marketing and so on, companies have begun to use outsourced services in order to acquire competitive advantage. Over 58\% of worldwide GDP comes from service industries; in addition, more than $17 \%$ of international trade is a trade in services. Miles [1] defined KIBS as P-KIBS and T-KIBS. P-KIBS help their clients navigate or negotiate complex systems such as social, physical, psychological and biological systems. T-KIBS are services that rely heavily on professional knowledge, thus, their employment structures are heavily weighted toward engineers and scientists. Muller and Zenker [2] extended the definition of KIBS to include 'consultancy' firms, another general definition is provided by Tovoinen [3], who defined KIBS as expert companies that provide services to their clients or organizations. Previous research has looked only at KIBS, rather than including the relationship with clients in order to study the effects of KIBS. Some scholars have explicitly studied the role of permanent geographical proximity for the production and consumption of these services [4]. Many studies in the past have taken the perspective of the 
KIBS side. Although there are some studies of KIBS in Asia [5-7], however, we found that there is a lack of research on KIBS in Japan, despite Japan having the second largest GDP in the world and many well-known manufactures and service industries. Our study focuses on the relationship between KIBS and clients in Japan by taking the clients' perspective in order to describe the optimal pattern of cooperation between both sides.

In our study, radical innovation and incremental innovation are distinguished based on the different divisions of JMCs that have dealt with KIBS. To examine differences between incremental and radical innovation, we first have to define these categories. Measures of product innovation have been critically discussed by Garcia and Calantone [8]. Following their arguments, we believe the dichotomy is too simplistic. Furthermore, there is a lack of conformance in defining innovation and empirical results based on different definitions that cannot be compared. Therefore, we concentrate on new product development projects that are considered incremental or radical by most of the related research and do not include in our analysis, innovation with a 'medium' degree of innovativeness, called, for example 'really new' or 'moderately innovative' [9]. The R\&D divisions of JMCs generally focus on radical innovation, while the production division works more on incremental innovation because they are more familiar with the market situation and closer to the customers.

The aim of this study is three-fold. Because of the lack of research on KIBS in Japan, first we focus on the relationship between KIBS and clients in Japan by taking the view of the client-side and analyzing the utilization of KIBS for two different types of innovation. Second, the different divisions of JMCs have their own reasons for the service delivery from KIBS, so, based on distinguishing radical innovation and incremental innovation, we attempt to survey the impact of KIBS on the different divisions. Third, we try to shed light on KIBS in Japan. The present situation and trends of their relationships with their manufacturing clients are described based on the findings of our questionnaire.

\section{Analytical framework and hypotheses}

Our study attempts to investigate the relationship between service delivery by KIBS and the satisfaction of the different divisions of JMCs. The different divisions of respondents were distinguished and we set up three groups: Group (1) is the R\&D division; group (2) the production division; other divisions are included in group (3). We interviewed over 100 people who belong to different divisions. We found that different divisions have different purposes when they deal with KIBS. Solving technical problems and getting ideas for new products are the main purposes of the R\&D divisions for dealing with KIBS. In contrast, the production division and other divisions tend to solve problems that are not so technical, for example, reducing the cost of a product or some consultancy regarding market. With this in mind, we separated the main purpose of each group and the types of innovation.

We suppose that JMCs usually solve their problems by themselves, and they will turn to KIBS for help if they face serious problems that they cannot solve. When KIBS provide their service that relies on professional knowledge to their client, the way of service delivery is very important. Vanchan [10] pointed out that a faceto-face way of service delivery is necessary for relationship-building and long-term success. Mccole and Ramsey [11] also pointed out that the internet can create a more innovative environment to firms although it will create some obstacles and KIBS should take it as an opportunity for wining competitive advantage rather than a reason to postpone its adoption.

As we described earlier, KIBS produce and diffuse the knowledge that is crucial for innovation processes. Simmie and Strambach [12] also pointed out that KIBS make a significant and place specific contributions to innovation, not only of firms, but also in the cities where they are located. JMCs will have different problems during the process of innovation, and generally they try to solve them by themselves, but when the problems are too serious to solve they will turn to KIBS. As we discussed, there are some differences between radical innovation and incremental innovation, and different divisions have their own reasons for dealing with KIBS. For example, the R\&D division, rather than other divisions, always has problems regarding technology, and the "really new" product idea usually comes from it. On the other hand, the production division or other divisions have closer relations with the market and customers; all kinds of problem in these divisions do not need services that rely on technology as much as the R\&D division does.

H1: KIBS contribute to the radical innovation of clients rather than the incremental innovation.

The method of service delivery contributes to the satisfaction of divisions after they deal with KIBS. Some methods of service delivery included in our study are as follows: face-to-face, internet, third intermediary party 
and by manuals or related documents. We suppose that no matter what division, JMCs all tend to get service from KIBS by the face-to-face way not only because it is more efficient for exchanging and sharing intangible assets between both sides, but also because the services provided by KIBS rely on professional knowledge.

H2: when the R\&D division deals with KIBS, the face-to-face method of service delivery is the most efficient method to insure high quality service from KIBS.

H3: when the production division and other divisions deal with KIBS, the face-to-face method of service delivery is the most efficient method of avoiding obstacles regarding the mobility of human resources.

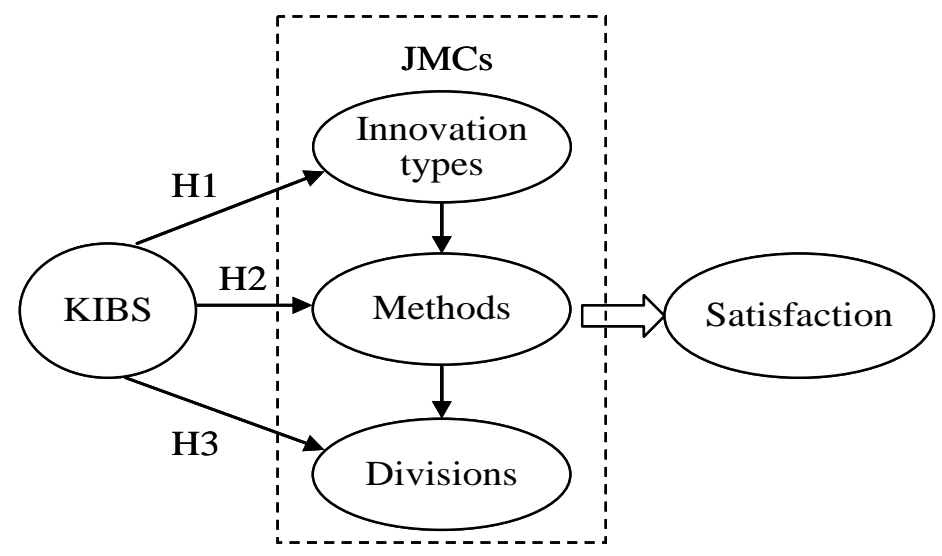

Fig. 1 Analytical framework and research hypotheses

Figure 1 illustrates this study's analytical framework and research hypotheses. It examines the relationship between service delivery by KIBS for the two types of innovation of different divisions based on their own purpose and the satisfaction of the divisions. The client will choose the KIBS based on the different types of Innovation and the different methods of service delivery. Therefore, we attempted to investigate, firstly, what is the most efficient method from KIBS that JMCs use, then we explore the criteria for choosing KIBS by JMCs. Furthermore, we focus on service provision, especially the way of service delivery and the benefits to their clients. The study focuses on the divisions of JMCs that deal with KIBS then discusses the utilization of KIBS for innovation.

\section{Research methods and samples}

\section{1 Research methods}

This study relies on questionnaires and interviews with JMCs. The factors obtained from the previous research and exploratory interviews were verified in a pilot study and a pre-test. The purpose of the pilot study and the pre-test was (a) to assess the validity of the constructs and to adjust further the scales if necessary and (b) to evaluate and improve the quality of questionnaire before conducting the survey. Two organizations cooperated in our survey regarding the selection of respondents. The first was the Business Research Institute (BRI). The BRI plays a major role in promoting innovation of Japanese companies. The other was the Japan Productivity Center (JPC). The JPC encourages productivity in Japan's industrial society and consist of more than 10000 companies and organizations in Japan. The questions relate to comments and grades that have multiple-item measures, with 7-point Liker-type scales ranging from 1 for "strongly disagree" to 7 for "strongly agree" and 1 for "objectives not achieved" to 7 for "objectives exceeded". We distributed the questionnaire in Oct 2008 and received the final written reply in Jan 2009. Next, interviews were conducted with all the respondents to our questionnaires between Feb 2009 and Apr 2009 in order to verify the accuracy of the 
respondents' answer, to determine the reason for the statistical analysis results, and to supplement the survey data and further probe into the background behind the survey results.

After data collection, we firstly checked the information of respondents, keeping that which exhibited desirable psychometric properties. Measures for each respondent showed acceptable internal consistency based on coefficient alphas of 0.846 for the scales and reliability levels. We analyzed the data first in correlation model and then regression model by SPSS version 17.0. The correlation analysis explored the relations regarding the hypotheses among variables and the regression analysis contributed to further details of the relationships. In addition, we conducted in-depth interviews with respondents and KIBS companies in order to determine the reason for the statistical analysis results.

\section{2 Samples}

We reviewed the literature on KIBS [1-3] and developed a standardized questionnaire to assess relations between KIBS and JMCs. For the large-scale study, we identified a total of 1000 individuals from mechanical, electrical, pharmaceutical, chemical and engineering companies. Many large Japanese corporations have sped up and streamlined decision-making by using spin-offs, divisionalized organization, company-based organization and other measures to transfer responsibility and authority to the individual operating divisions on a wholesale basis. They have also introduced systems for holding employees responsible for their performance. Therefore, it is presumed that a large corporation has many different relationships with KIBS. We sent the questionnaire to 1000 people who work for JMCs. One third of our sample were R\&D directors, one third were production managers and one third were other division's managers of JMCs. Out of 1000 questionnaires, 256 were returned, which represents a response rate of $25.6 \%$. For the purpose of this study, respondents were asked to describe the relationship with KIBS during last ten years, this definition includes past relationships that have ceased at the present time.

The respondents' companies participating in our study had been from between below 1000 to more than 100000 employees and annual sales ranging from 70 million JPY (Japanese Yen) to 4.6 trillion JPY. The majority of the firms consist of medium to large-size companies employing 100 to 10000 employees and having annual sales between 1 billion and 1 trillion JPY. In addition, the range of the companies' capital is from 100 million to one trillion JPY. 187 of the 256 companies are independent, while 65 describe themselves as dependent subsidiaries of larger corporations.

\section{Model estimation and results}

We separated all the respondents into two groups based on the type of innovation that they usually tend to develop. R\&D divisions (group A) usually work on solving high technical problems and getting ideas for really new products. This implies that, compared to other divisions, the R\&D division tends to have radical innovation. On the other hand, the production divisions and other divisions (group B) generally change existing products in the market and they have closer relationship with the customer, and they tend to have incremental innovation. This in mind, we selected the relevant data and tested these relationships using the correlation analysis model and regression analysis model of SPSS 17.0.

For radical innovation, we focus on the service provided by KIBS. The related variables are solving patent, design, utility model, copyright, trade mark, trade secret, tacit knowledge, explicit knowledge and know how. In addition, we described the satisfaction of both groups as: a need for KIBS in the future, KIBS as the key of innovation, manufacturing and service will amalgamate, KIBS is increasing the source of profit and KIBS will become normal practice. The table 1 shows that the service delivery from KIBS has a significant and strong correlation with the satisfaction of the R\&D divisions. Compared to group A the results of table 2 show that the services provided by KIBS do not have a significant and strong relationship with the satisfaction of production and other divisions. Patent does not contribute to the satisfaction of either group. Design has a significant positive correlation with a need for KIBS in the future, KIBS is the key to innovation and KIBS is an increasing source of profit. In group A, the corresponding coefficients are .370 $(\mathrm{p}<.01), .320(\mathrm{p}<.01)$ and $.328(\mathrm{p}<.01)$. However, design has no relation with satisfaction in group B. Utility model, copyright and trade mark have no 
relation or a strong negative correlation with the satisfaction of both groups. We suppose that these types of services are not expected by either group. Furthermore, trade secret has significant positive correlation with the variable of manufacturing and KIBS will amalgamate and KIBS is an increasing source of profit in table 1, the related values are $.339(\mathrm{p}<.01)$ and $.223(\mathrm{p}<.05)$. On the other hand, trade secret only has a positive correlation with the need for KIBS in the future in table 2, the corresponding coefficient is .344 $(\mathrm{p}<.05)$. We found that knowledge has a significant positive correlation with the satisfaction of both groups, the standardized coefficients of group A are $.390(\mathrm{P}<.01), .352(\mathrm{P}<.01), .387(\mathrm{P}<.01), .364(\mathrm{P}<.01), .330(\mathrm{P}<.01)$ and $.395(\mathrm{p}<.01)$; the related values of table 2 are $.521(\mathrm{p}<.01), .525(\mathrm{p}<.01), .343(\mathrm{p}<.05), .523(\mathrm{p}<.01), .517(\mathrm{p}<.01)$ and .386 $(\mathrm{p}<.05)$. The relationships between the services provided by KIBS and the satisfactions of R\&D divisions are stronger and more significant than the related values of the production and other divisions. In table 1 , knowledge also has a strong and positive correlation with KIBS is an increasing source of profit, the corresponding coefficients are $.389(\mathrm{p}<.01)$ and $.374(\mathrm{p}<.01)$. We suppose that KIBS provide their services to different divisions for their different types of innovation and that the KIBS contribute to radical innovation rather than incremental innovation. These results support our hypotheses 1.

Table 1 Result of correlation analysis of group A for hypothesis 1

\begin{tabular}{|c|c|c|c|c|c|c|c|c|c|}
\hline Indicators & Patent & Design & $\begin{array}{l}\text { Utility } \\
\text { model }\end{array}$ & $\begin{array}{c}\text { Copyri } \\
\text { ght }\end{array}$ & $\begin{array}{l}\text { Trade } \\
\text { mark }\end{array}$ & $\begin{array}{l}\text { Trade } \\
\text { secret }\end{array}$ & $\begin{array}{c}\text { Tacit } \\
\text { knowledge }\end{array}$ & $\begin{array}{c}\text { Explicit } \\
\text { knowledge }\end{array}$ & $\begin{array}{c}\text { Know } \\
\text { how }\end{array}$ \\
\hline KIBS in the future & .125 & $.370^{* *}$ & .007 & $-.250^{*}$ & .040 & .158 & $.390 * *$ & $.364^{* *}$ & .172 \\
\hline $\begin{array}{l}\text { KIBS is the key to } \\
\text { innovation }\end{array}$ & .143 & $.320 * *$ & -.179 & $\begin{array}{l}- \\
.299 \\
* *\end{array}$ & .046 & .190 & $.352 * *$ & $.330 * *$ & .215 \\
\hline $\begin{array}{c}\text { KIBS will } \\
\text { amalgamate }\end{array}$ & -1.25 & .210 & -.126 & $\begin{array}{l}- \\
.665 \\
* *\end{array}$ & -.106 & $.339 * *$ & $387 * *$ & $.395 * *$ & .200 \\
\hline $\begin{array}{c}\text { More profit form } \\
\text { KIBS }\end{array}$ & .065 & $.328 * *$ & $-.239 *$ & $-.231 *$ & .067 & $.223 *$ & $.389 *$ & $.374^{* *}$ & .186 \\
\hline $\begin{array}{l}\text { KIBS become } \\
\text { normal practice }\end{array}$ & .212 & .155 & .102 & -.164 & .116 & -.066 & .162 & .080 & .157 \\
\hline
\end{tabular}

Note: *Significant at $\mathrm{p}<.05$ level, **Significant at $\mathrm{p}<.01$ level

Table 2 Result of correlation analysis of group B for hypothesis 1

\begin{tabular}{lccccccccccc}
\hline \multicolumn{1}{c}{ Indicators } & Patent & Design & $\begin{array}{c}\text { Utility } \\
\text { model }\end{array}$ & Copyright & $\begin{array}{c}\text { Trade } \\
\text { mark }\end{array}$ & $\begin{array}{c}\text { Trade } \\
\text { secret }\end{array}$ & $\begin{array}{c}\text { Tacit } \\
\text { knowledg } \\
\mathrm{e}\end{array}$ & $\begin{array}{c}\text { Explicit } \\
\text { knowledge }\end{array}$ & $\begin{array}{c}\text { Know } \\
\text { how }\end{array}$ \\
\hline $\begin{array}{l}\text { KIBS in the future } \\
\text { KIBS is the key }\end{array}$ & to & -030 & -.052 & .112 & .248 & - & $.344^{*}$ & $.521^{* *}$ & $.523^{* *}$ & $.560^{* *}$ \\
$\begin{array}{l}\text { innovation } \\
\text { KIBS will amalgamate }\end{array}$ & -.078 & .019 & .186 & -.072 & - & .143 & $.525^{* *}$ & $.517^{* *}$ & $.349^{*}$ \\
More profit form KIBS & -.100 & -.050 & .086 & .023 & - & -.151 & .204 & .180 & .171 \\
KIBS become normal practice & .022 & -.261 & $-.469 * *$ & -.104 & - & -.191 & .031 & .145 & .066 \\
\hline
\end{tabular}

Note: *Significant at $\mathrm{p}<.05$ level, **Significant at $\mathrm{p}<.01$ level 
The data show that when the divisions of JMCs deal with KIBS they all tend to receive services by face-toface method. $98.7 \%$ of R\&D divisions chose this way, $96 \%$ of production divisions and $100 \%$ of other divisions made the same choice as the R\&D divisions. This implies that face-to-face method of service delivery is the most efficient or important method for service deliveries between KIBS and clients. Our study attempts to investigate and explore the reasons for this. We focus on the relationships between the obstacles that occur when clients deal with KIBS using face-to-face method of service delivery. We suppose that this method contributes to avoiding some obstacles and insures the quality of service delivery from KIBS. The obstacles we considered are described as price of service, quality of service, profit sharing, security of knowledge, location, business cultural gap, laws and regulations, mobility of human resources and rights to ideas. The results of table 3 show that when R\&D divisions deal with KIBS they tend to get face-to-face service delivery in order to insure the quality of service. The quality of service has a significant and strong positive correlation with face-to-face method, the corresponding coefficient is .498 $(\mathrm{p}<.01)$. On the other hand, the respondents consider that face-to-face has significant negative correlations with security of knowledge and right to ideas, the corresponding standardized coefficients are $-.234(\mathrm{p}<.05)$ and $-.346(\mathrm{p}<.01)$. This implies that sometimes face-to-face method of service delivery causes obstacles regarding the security of knowledge and the right to ideas because knowledge or other intangible assets are shared efficiently by face-to-face. Probably the R\&D divisions tend to think that they can only get a high quality of service by face-to-face so they take the risk of the related obstacles. Table 4 shows the results of the correlation analysis of group B for hypothesis 3. We found that for production divisions and other divisions, the face-to-face method is a very efficient way to solve the problems regarding mobility of human resources. There is a very strong and positive correlation between them, the value is $.474(\mathrm{p}<.01)$. Although the production divisions and other divisions do not need the services that rely on professional knowledge as heavily as R\&D divisions, they do still need the knowledge provided by KIBS. The face-to-face method of service delivery is very helpful for sharing and exchanging intangible assets among people. Therefore, knowledge or other intangible assets will not be monopolized by a few people, reducing or even avoiding the risks of mobility of human resources. Hypothesis 2 and hypothesis 3 are supported by the results.

Table 3 Result of correlation analysis of group A for hypothesis 2

\begin{tabular}{|c|c|c|c|c|c|c|c|c|c|}
\hline $\begin{array}{l}\text { Service } \\
\text { delivery } \\
\text { method }\end{array}$ & Price & Quality & $\begin{array}{c}\text { Profit } \\
\text { sharing }\end{array}$ & $\begin{array}{l}\text { Security of } \\
\text { knowledge }\end{array}$ & Location & $\begin{array}{c}\text { Cultural } \\
\text { background }\end{array}$ & $\begin{array}{c}\text { Laws \& } \\
\text { regulations }\end{array}$ & $\begin{array}{l}\text { Mobility } \\
\text { of HR }\end{array}$ & $\begin{array}{l}\text { Rights to ideas } \\
\text { from } \\
\text { collaborations }\end{array}$ \\
\hline $\begin{array}{l}\text { Face to } \\
\text { face }\end{array}$ & .194 & $.498 * *$ & -.141 & $-.234^{*}$ & .026 & -.188 & -.096 & .035 & $-.346 * *$ \\
\hline
\end{tabular}

Note: *Significant at $\mathrm{p}<.05$ level, **Significant at $\mathrm{p}<.01$ level

Table 4 Result of correlation analysis of group B for hypothesis 3

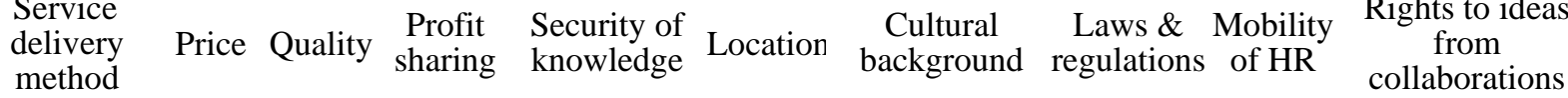

\begin{tabular}{llllllllll}
\hline $\begin{array}{c}\text { Face to } \\
\text { face }\end{array}$ & .204 & .299 & .249 & .078 & .296 & .007 & .047 & $.474 * *$ & -.257 \\
\hline
\end{tabular}

Note: *Significant at $\mathrm{p}<.05$ level, **Significant at $\mathrm{p}<.01$ level 
Furthermore, we analyzed the related data by using regression analysis of SPSS 17.0 to explore the results in more depth. Table 5 shows the relationship of regression between obstacles and the face-to-face service delivery method. The results imply that the face-to-face is helpful to all the divisions in avoiding some obstacles. On the other hand, face-to-face can easily cause some other obstacles, and has a strong positive regression correlation with price of service, quality of service, profit sharing and mobility of human resources, and the corresponding coefficients are .384 $(\mathrm{p}<.01), .484(\mathrm{p}<.01), .581(\mathrm{p}<.01)$ and $.235(\mathrm{p}<.01)$ respectively. Security of knowledge and right to ideas have significant negative regression correlations with the face-to-face method, the standard corresponding coefficients are -.288 $(\mathrm{p}<.05)$ and -.429 $(\mathrm{p}<.01)$. This implies that JMCs tend to choose the faceto-face service delivery method by KIBS because it contributes to the appropriate price of service, high quality of service, fair sharing of profit and strong human resources, even though they may face obstacles regarding security of knowledge or right to ideas. The results also support hypotheses 2 and 3.

Table 5 Result of regression analysis of all respondents

\begin{tabular}{|c|c|c|c|c|c|c|c|c|c|}
\hline $\begin{array}{l}\text { independ } \\
\text { ent } \\
\text { variables }\end{array}$ & Price & Quality & $\begin{array}{c}\text { Profit } \\
\text { sharing }\end{array}$ & $\begin{array}{l}\text { Security of } \\
\text { knowledge }\end{array}$ & Location & $\begin{array}{c}\text { Cultural } \\
\text { background }\end{array}$ & $\begin{array}{c}\text { Laws \& } \\
\text { regulations }\end{array}$ & $\begin{array}{c}\text { Mobility } \\
\text { of HR }\end{array}$ & $\begin{array}{c}\text { Rights to ideas } \\
\text { from } \\
\text { collaborations }\end{array}$ \\
\hline $\begin{array}{l}\text { Face to } \\
\text { face } \\
\text { dependent } \\
\text { variables }\end{array}$ & \multicolumn{9}{|c|}{ standardized coefficients } \\
\hline Adj.R ${ }^{2}$ & \multicolumn{9}{|c|}{0.391} \\
\hline F-value & \multicolumn{9}{|c|}{$9.285 * *$} \\
\hline $\mathrm{n}$ & \multicolumn{9}{|c|}{256} \\
\hline
\end{tabular}

Note: *Significant at $\mathrm{p}<.05$ level, **Significant at $\mathrm{p}<.01$ level

\section{ConclusionS}

Our study has several findings and managerial implications. Foremost is that this study points to the utilization of KIBS for the innovation of JMCs in Japan. Firstly, KIBS provide professional knowledge to accelerate the different innovation of their clients; secondly, KIBS contribute more to the radical innovation of a client rather than incremental innovation and the different divisions of JMCs all need human resource training services from KIBS; thirdly, face-to-face way is the most efficient method of service delivery from KIBS to the JMCs.

The second managerial implication is that our study takes the point of view of the client-side. We separate different divisions of respondents into different groups while testing our hypotheses. This helps us to explore their needs in detail and to show that the KIBS in Japan currently satisfy their clients. We chose the different respondents among different industries, and all are famous manufacturing corporations in Japan. Almost all of them have plenty of experience of dealing with KIBS, helping us to explore the service needs of JMCs from KIBS in detail and to show the relationship between KIBS and their clients.

The third managerial implication is that KIBS provide human resource training is presently the most popular for JMCs. The methods of service delivery are determined by the client; JMCs need custom-built services from KIBS and the face-to-face way or combining face-to-face with manuals and related documents are their preferred methods of service delivery from KIBS.

In the future, we will focus on two or three typical cases of manufacturing corporations that deal with KIBS and track their process of cooperation. In addition, we will set up a questionnaire related to KIBS in Japan in order to explore in more detail their relationships and validate the previous research. 


\section{Acknowledgment}

The authors would like to express our appreciation to all the firms, respondents, and interviewees who gave of their time to participate in this study. Also, we would like to thank Mr. Stuart Leopold and Mrs. Yamaguchi for their helpful comments and suggestions. This study was funded by the Grant-in-Aid for Humanities \& Social Science research foundation (Grant No: 07JA630003) from the Ministry of Education of China, and the Indigenous Innovation Research Foundation (Grant No: 2010AW021) from HUST of China.

\section{References}

[1] I. Miles. (1995) 'Knowledge-intensive business services-users, carriers and sources of innovation', A report to DG13 SPRINT-EIMS, pp.27-28.

[2] E. Muller and A. Zenker. (2001) 'Business services as actors of knowledge transformation: the role of KIBS in regional and national innovation systems’, Research Policy, Vol.30, No.9, pp. 1501-1516.

[3] M. Tovoinen. (2006) 'Future Prospects of Knowledge-Intensive Business Services (KIBS) and Implications to Regional Economies’, The ICFAI Journal of Knowledge Management, Vol. 4, No. 3, pp. 18-39.

[4] A Torre and A Rallet. (2005) 'Proximity and localization', Regional Studies, Vol.39, No.1, pp.47-59.

[5] Lee KR. (2004) 'Utilization of knowledge intensive services for the innovation of manufacturers in Korea', Journal of Technology Innovation, Vol.12, No.2, pp.263-267.

[6] Wei Jiang. (2006) 'pattern of innovation in KIBS', Science Research Management (in Chinese)”, Vol.27, No.1, pp.70-75.

[7] Wood. P. (2006) 'The regional significance of knowledge-intensive services in Europe', Innovation: The European Journal of Social Sciences, Vol.19, No1, pp. 51-66.

[8] Garcia, R. and Calantone, R. (2002). "A critical look at technological innovation typology and innovativeness terminology: a literature review”, Journal of Product Innovation Management, Vol. 19 No 2, pp.110-132

[9] Kleinschmidt, E.J. and Cooper, R.G. (1991). “The impact of product innovativeness on performance”, Journal of Product Innovation Management, Vol. 8 No 4, pp. 240-251

[10] Vanchan, V. (2007). "Communication and relationships between industrial design companies and their customers”, The Industrial Geographer, Vol. 4 No 2, pp. 28-46

[11] Mccole, P. and Ramsey, E. (2004). "Internet-enabled technology in knowledge-intensive business services: a comparison of Northern Ireland, the Republic of Ireland and New Zealand”, Marketing intelligence \& planning, Vol. 22 No 7, pp. 761-779

[12] Simmie, J. and Strambach, S. (2006). “The contribution of KIBS to innovation in cities: an evolutionary and institutional perspective”, Journal of knowledge management, Vol. 10 No 5, pp. 26-40 